\title{
Goat Bite in an Infant: Ecthyma Contagiosum
}

\author{
Infant Bir Olguda Keçi Isırığı: Ektima Kontagiyozum
}

\author{
Fatih İsleyen'(iD), Mehmet Tekin²(iD), Çapan Konca²(iD), İbrahim Hakan Bucak²(ID), Mehmet Turgut²(iD) \\ ${ }^{1}$ Clinic of Neonatoloyg, Ankara Etlik Zübeyde Hanim Gynecology Training and Research Hospital, Ankara, Turkey \\ ${ }^{2}$ Department of Pediatrics, Adiyaman University School of Medicine, Adiyaman, Turkey
}

Cite this article as: Işleyen F, Tekin M, Konca Ç, Bucak iH, Turgut M. Goat bite in an infant: ecthyma contagiosum. J Pediatr Inf 2020;14(3):e138-e140.

Abstract

Orf disease is a zoonotic disease caused by the Orf virus, a member of the Parapoxvirus family, which can be transmitted to humans from sheep and goats. Since transmission occurs from cracks and fissures in the skin, the lesions are generally seen in the hands and fingers. Diagnosis is usually based on clinical findings compatible with the patient history. Awareness of this disease will therefore prevent unnecessary advanced tests and treatments. Orf disease is generally self-limiting without complications and resolves without treatment, although it may rarely be accompanied by fever and secondary infections. This report is presented due to being the youngest case of Orf disease resulting from a goat bite and complications developing during the course of the disease.

Keywords: Orf, ecthyma contagiosum, infant

\section{Introduction}

Orf disease is a viral cutaneous zoonotic infection capable of transmission to humans through direct or indirect contact with animals such as usually sheep, goats rarely cat, camel and Japanese mountain goats. The disease is commonly seen in spring and summer. Lesions generally appear on the hands, fingers, and arms, and more rarely on the face, and may be single or multiple. Complications are rare, although fever, secondary bacterial infections, lymphadenitis, and erythema multiforme have been reported (1-3).
Öz

Orf hastalığı, Parapoxvirus ailesinden Orf virüsün etken olduğu koyun ve keçilerden insanlara bulaşabilen bir zoonozdur. Derideki yarık ve çatlaklardan bulaş olduğundan lezyonlar genellikle eller ve parmaklarda görülür. Tanı çoğunlukla klinik bulguların hastanın öyküsü ile uyumlu olmasıyla koyulur. Bu nedenle hastalığın bilinmesi gereksiz ileri tetkik ve tedavileri engelleyecektir. Orf hastalığı genellikle komplikasyon gelişmeden kendini sınırlayan ve tedavisiz iyileşen bir hastalık olmakla birlikte nadiren ateş, sekonder bakteriyel enfeksiyonlarla beraberlik göstermektedir. Bu yazı, keçi ısırığı sonrasında ortaya çıkan literatürdeki en küçük Orf hastası olması ve hastalığın komplikasyonla seyretmesi nedeniyle sunulmuştur.

Anahtar Kelimeler: Orf, ektima kontagiyozum, infant

\section{Case Report}

A 10-month-old girl presented to our hospital due to swelling and bruising on the fourth and fifth fingers of the left hand and was admitted to the infant ward. The patient had been bitten by a goat four weeks previously. Swelling appeared in the fourth and fifth fingers of the left hand two weeks after the event. The patient then presented to an external center, and topical treatment was administered. The patient used the prescribed medication for one week, but then presented to us due to fever and worsened symptoms. Physical examination 


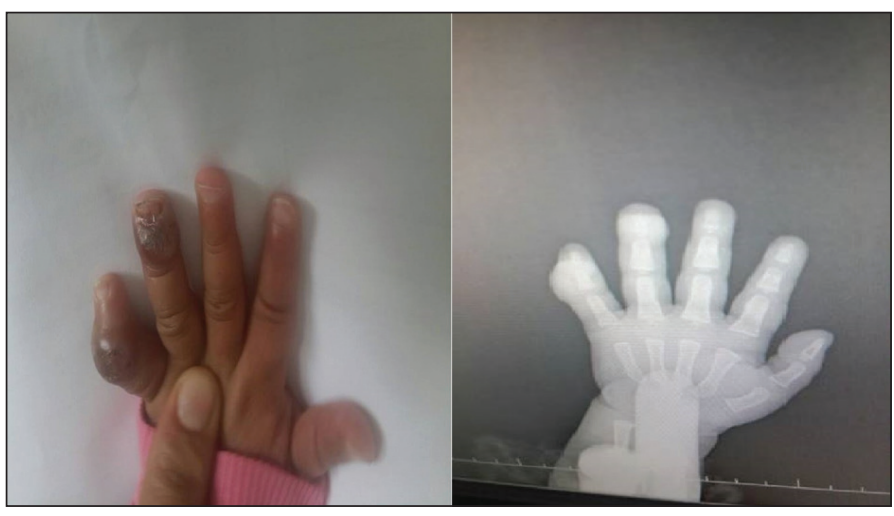

Figure 1. Papulonodular ecchymotic lesions on admission.

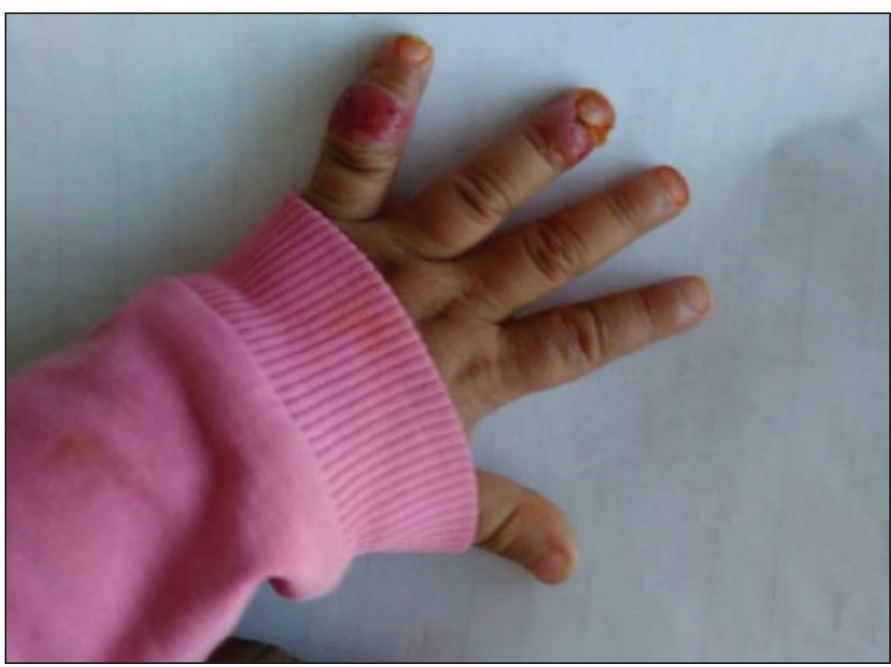

Figure 2. Regression of lesions after treatment.

revealed papulonodular ecchymotic lesions with black dots, $0.5 \times 0.5 \mathrm{~cm}$ in size on the left fourth distal phalanx and $0.6 \mathrm{x}$ $0.8 \mathrm{~cm}$ on the proximal interphalangeal joint on the fifth phalanx (Figure 1). Other system findings were normal. The patient's erythrocyte sedimentation rate, $22 \mathrm{~mm} /$ hour (normal range $0-20 \mathrm{~mm} /$ hour), and C-reactive protein values, $1.8 \mathrm{mg} / \mathrm{L}$ (normal range 0-0.5 mg/L), were elevated, while other laboratory values were normal. Orf disease was diagnosed based on the patient's history and the clinical appearance of the lesions. Fever, persistence of the Orf lesions, and acute phase reactant positivity were attributed to secondary bacterial infection. Systemic antibiotherapy (cefazolin sodium), antibacterial pomade, and wound care with local antiseptic were applied. The patient was followed-up for 10 days, and the lesions resolved (Figure 2).

\section{Discussion}

Orf disease is a viral disease unique to animals that is generally seen in the mouths, lips and non-hairy skin of newborn kids and lambs in spring. The incubation period is shorter than three weeks (4). Lesions in our case began appearing two weeks after a goat bite. Orf disease was diagnosed without the need for advanced tests due to the presence of the lesions on the hand, the most common site, the presence of a powerful epidemiological history, and the typical lesion appearance in our case presenting to hospital approximately two weeks after lesion onset.

Orf disease has generally been reported in adults although there have also been pediatric cases. Children are reported to be at greater risk of zoonotic infections due to a greater tendency to be bitten by animals, and insufficient attention to hand hygiene and protective measures. It is important to distinguish Orf disease from anthrax. Cutaneous anthrax appears in the form of a red papule, then progresses to a black necrosis ulcer. Edema and regional painful lymphadenopathy are frequently seen in the tissue surrounding the lesion (5).

Diagnosis can be confirmed by clinical findings, histological examination, and detection of the virus DNA with real time PCR techniques. Histological findings vary depending on the stage of the disease $(1,3)$. No histopathological examination was performed in our case due to regression of the lesions. Since the disease is self-limiting, no special treatment is required, although antibiotics should be used if secondary bacterial infection develops. Surgery is not recommended unless the lesions are very large and progressive. Antibiotherapy was administered due to fever and secondary infection in our case, but no special treatment for Orf disease was applied.

In conclusion, Orf disease is generally seen in adulthood, but can also occur in childhood. Complications are rare. This case is reported due to being the youngest Orf disease patient reported to date, based on our review of the literature, and the development of complications.

\section{Informed Consent: Patient consent was obtained.}

Peer-review: Externally peer-reviewed.

Author Contributions: Concept - FI, MT; Design - Fi, ÇK; Supervision - MT, MT; Resources - Fi, iHB; Data Collection and/or Processing - Fi, ÇK; Analysis and/or Interpretation - ÇK, MT; Literature Review - ÇK, IHB; Writing - Fi, MT; Critical Review - ÇK, MT.

Conflict of Interest: No conflict of interest was declared by the authors.

Financial Disclosure: The authors declared that this study has received no financial support.

\section{References}

1. Sanchez RL, Hebert A, Lucia H, Swedo J. Orf: a case report with histologic, electron microscopic, and immunoperoxidase studies. Arch Pathol Lab Med 1985;109:166-70. [CrossRef]

2. Maman M, Medhioub Y. A case of Orf disease complicated by erythema multiforme. Arch Pediatr 2017;24:1241-3. [CrossRef] 
İşleyen et al.

3. Joseph RH, Haddad FA, Matthews AL, Maroufi A, Monroe B, Reynolds M. Erythema multiforme after orf virus infection: a report of two cases and literature review. Epidemiol Infect 2015;143:385-90. [CrossRef]

4. Alian S, Ahangarkani F, Arabsheybani S. A case of Orf disease complicated with erythema multiforme and bullous pemphigoid-like eruptions. Case Rep Infect Dis 2015;2015:105484. [CrossRef]
5. Bayindir Y, Bayraktar M, Karadag N, Ozcan H, Kayabas U, Otlu B, et al. Investigation and analysis of a human orf outbreak among people living on the same farm. New Microbiol 2011;34:37-43. [CrossRef] 